\title{
HYSTERESIS LOOPS FOR TIMBER STRUCTURES
}

\author{
D. J. Dowrick
}

\begin{abstract}
This paper reviews experimentally determined hysteresis loops for timber structures, including momentresisting joints with (i) steel and (ii) plywood side plates, (iii) shear walls clad with various materials, and (iv) push-pull tests on various connection details. The paper compares bending and push-pull hysteresis loops for nailed steel side-plate joints. An attempt is made to classify the above hysteretic behaviour for analytical purposes, and the available computer models are reviewed for applicability to these hysteresis shapes.
\end{abstract}

1.

\section{INTRODUCTION}

This paper is one of a series of papers on the design of timber structures for wind and earthquake resistance, resulting from the work of a joint comittee of the New Zealand Timber Design society and the New zealand National Society for Earthquake Engineering.

While of general interest to researchers and designexs in the construction industry, this study had a specific purpose as the first stage in a series of studies for detemining the SM product ( $s=$ structural qype factor $\mathrm{H}=$ Material Type Eactor required for assessing the level of lateral seismic load using the provisions of the New Zealand Loadings Code.

\section{EXPERIMENTALLY-DETERMINED} HYSTERESIS LOOES

\subsection{Moment-Resisting Joints -} Steel Side Plates

Section $A$ of the references gives five sources of hysteresis loops for this situation, of which the first (Ref $A I$ ) is derived from $A 3$ and $A 4$. Hence the list reduces to four ultimate sources, of which two (A3, A4) concern the behaviour of single joints, and the other two (A2, A5) concern portal frame behaviour. These are discussed below.

\subsubsection{Nail yielding joints}

The

two latter

studies demonstrate similar frame behaviour under cyclic loads (ie similar loop shape) of the type shown in Fig 1 with moderate

* Physics and Engineering Laboratory. DSIR, Lower Hutt pinching at a drift of $H / 100$ (ie 1 percent). Because of the large influence of the elastic bending deformations of the timber members, the strength plateau is only reached at excessive deformations. Figure 2 shows the similarity of typical loop shapes from the two studies. The repeated slow cycling behaviour of single joints also showed similarity in loop shape.

Comparisons of individual loop shapes for single $T$ joints and complete portal frames were made (Fig 2). The general similarity of shape exhibited may be expected because the timber member length per joint is roughly similar in all cases, ie the ratio of work done in the member to that done in the joint is similar in all cases.

The significant feature of the comparison between frame behaviour and joint behaviour is the fact that the high ductility of the yielding nails occurred at joint rotations implying excessive drift of the corresponding frames.

\subsubsection{Yielding steel plate joint}

The necked steel joint detail studied in ReF A4 was designed so that the steel plate yielded and not the nails. This ensured that the hysteretic behaviour of the joint followed the classical steel form of stable nearly elasto-plastic loops shown in Fig 3 .

\subsection{Moment-Resisting Joints}

\section{- plywood side plates}

Section $B$ of the references gives four sources of hysteresis loops for this situation, of which the first (Ref Bl) concerns the behaviour of a complete portal frame, while the remainder examine single joints. 


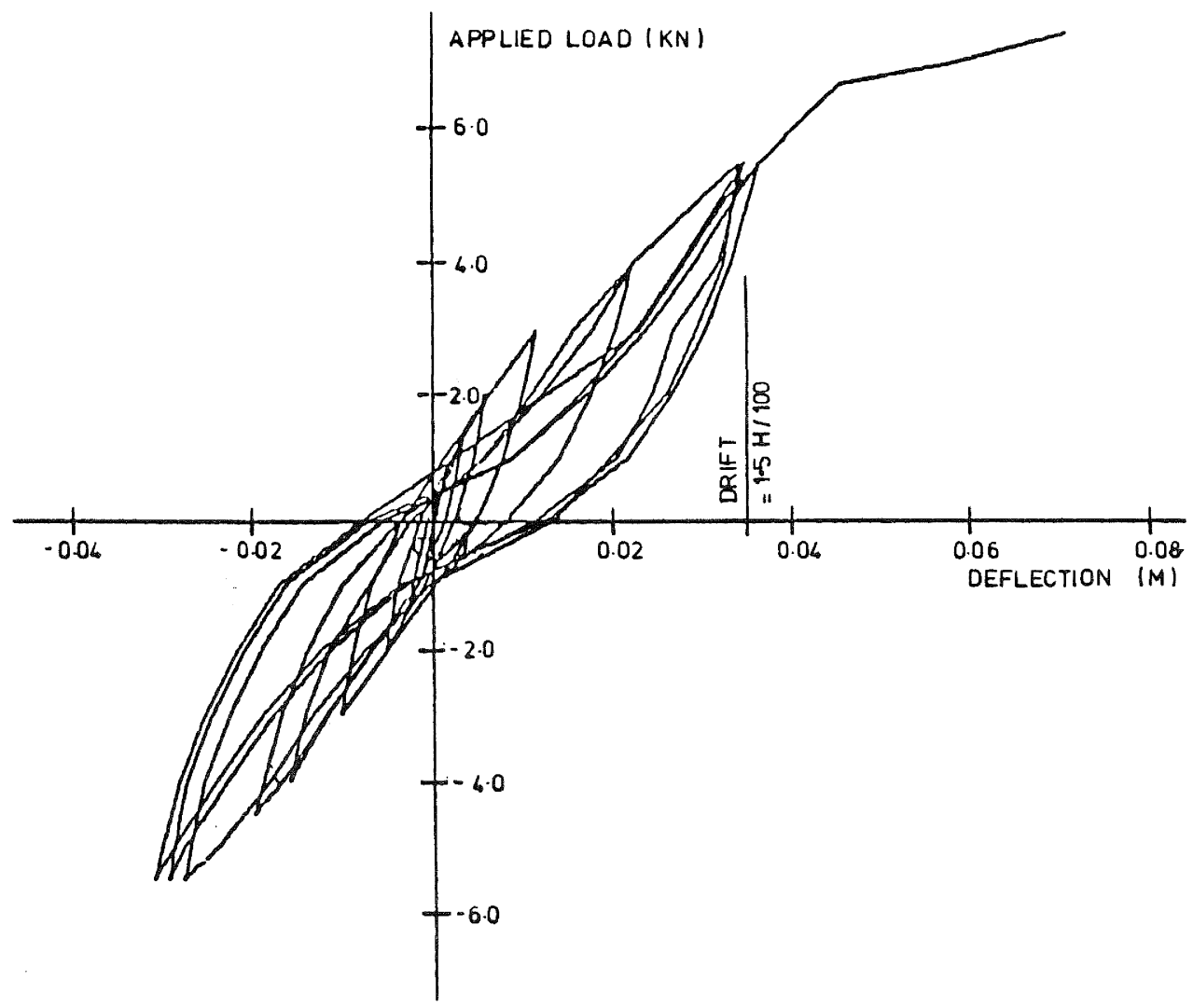

Fig 1. LOAD DEFLECTION HYSTERESIS LOOPS FOR MOMENT-RESISTING JOINT WITH STEEL SIDE PLATES (REF A2)

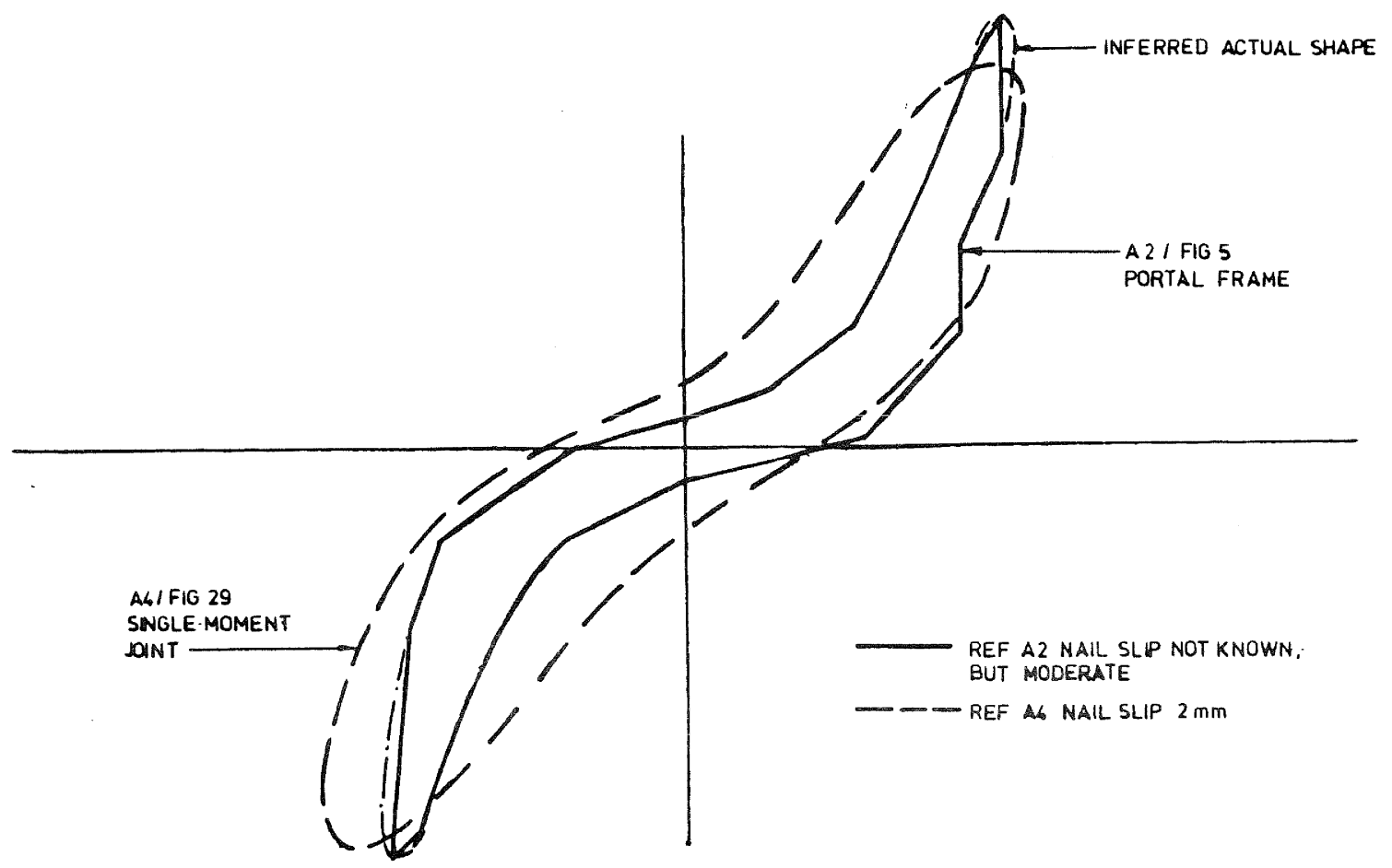

Fig 2. COMPARISON OF LOAD-DEFLECTION HYSTERESIS LOOPS FOR MOMENT-RESISTING JOINTS WITH STEEL SIDE PLATES (REFS. A2 AND A4). 


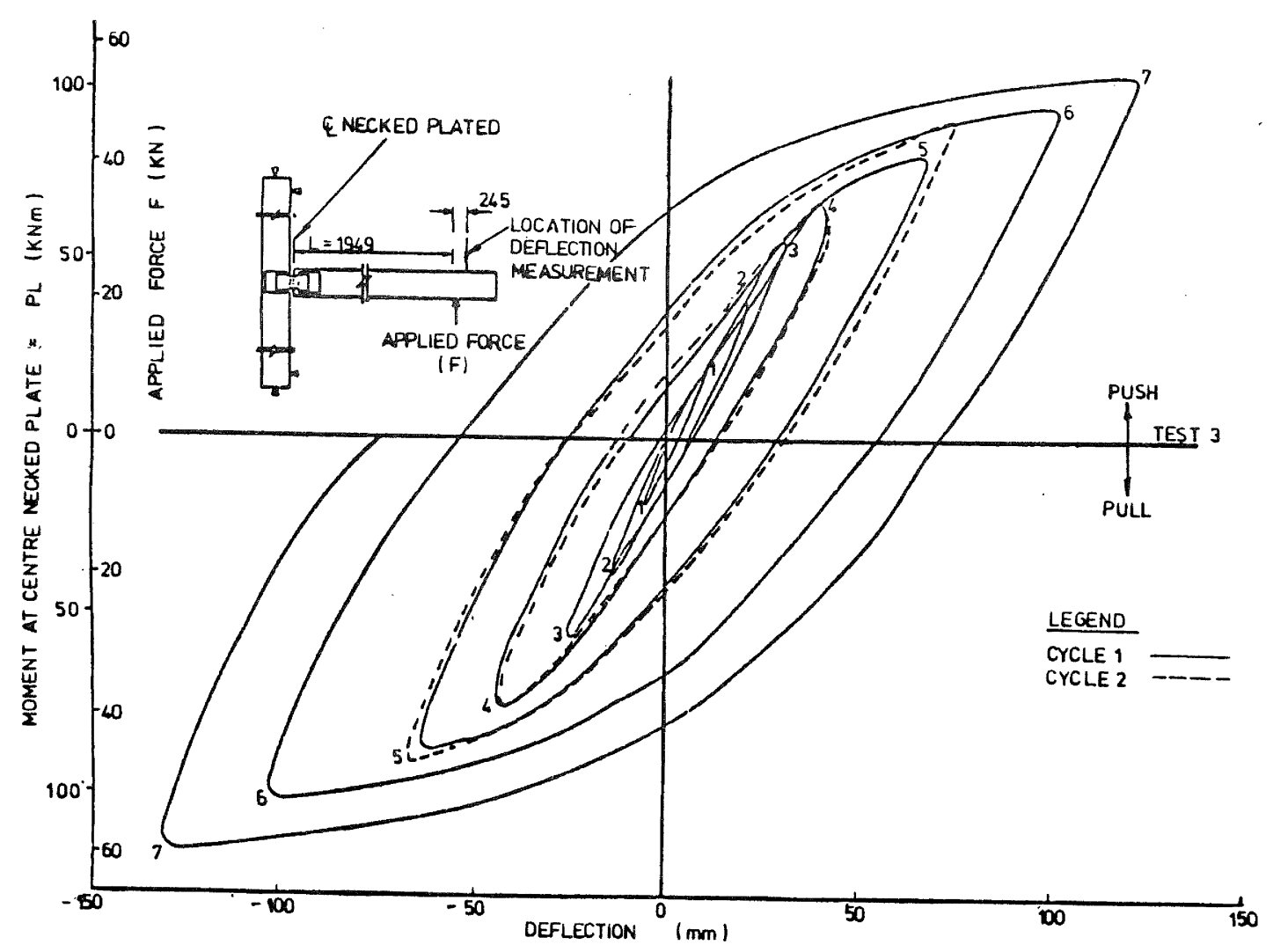

Fig 3. HYSTERESIS LOOPS FOR YIELDING STEEL PLATE JOINT (REF A4)

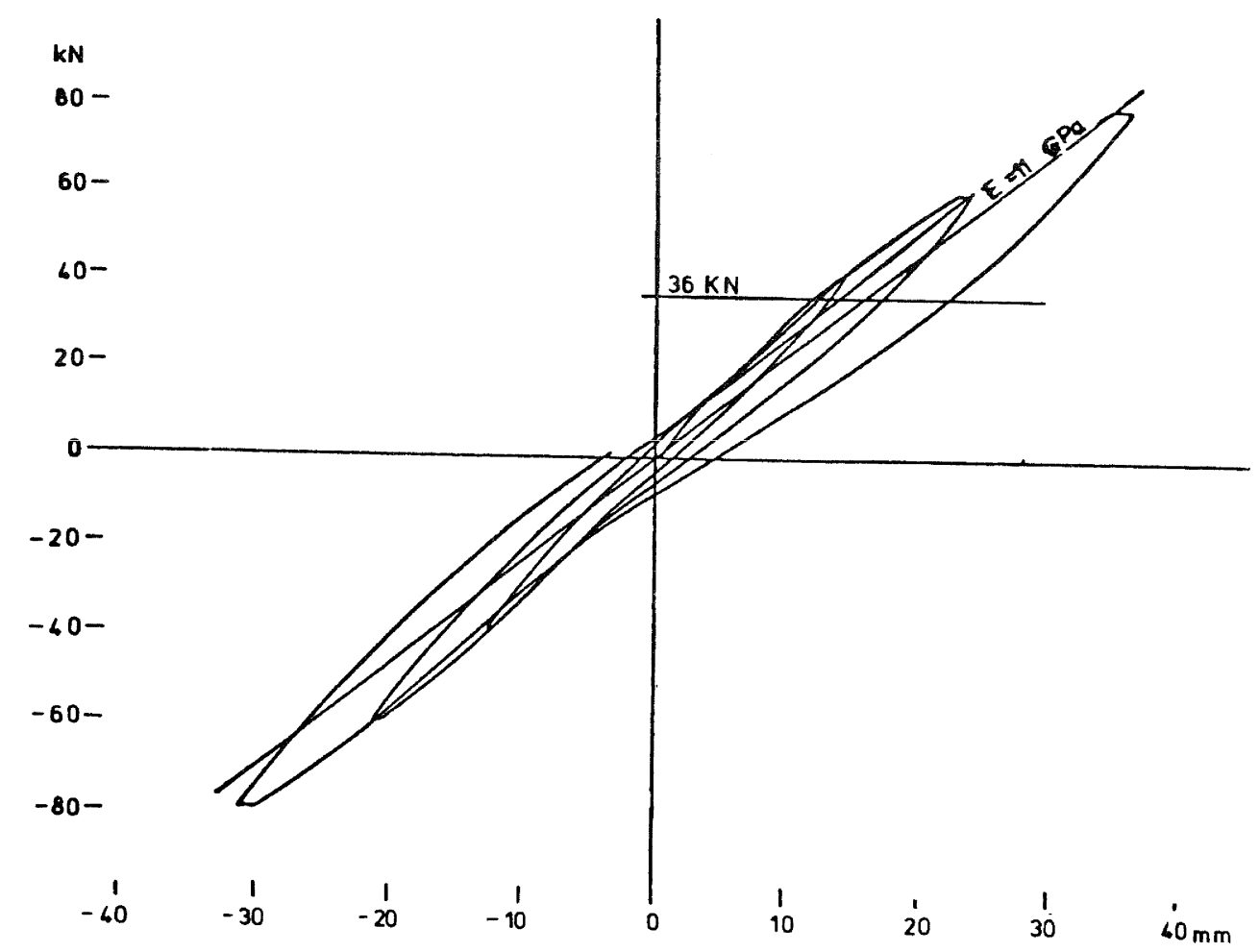

Fig 4. HYSTERESIS LOOPS FOR MOMENT-RESISTING JOINT WITH PLYWOOD SIDE PLATES (REF. B1) 
Figure 4 shows the results of repeated slow cyclic loading tests from one of the studies, and typifies the general similarity of behaviour of the results of all four studies. While pinching is moderate in all tests, the single joint tests perhaps show less of this effect than does the portal frame. The reverse might normally be expected if the influence of timber bending deformations is less in the single joint tests, and suggests that the number of nails used may be excessive in the latter tests.

In contrast to the steel side plate specimen discussed above, flattening of the backbone curve is not displayed within the cycling load range, and the unloading curve tends to be close to parallel to the loading curve without any significant lengths of zero change in deflection, ie no fat loops have been reported. This may be because the nails bend in single curvature with plywood side plates and in double curvature with steel side plates, thus placing less ductility demand on the nails in the former case.

Also this thin loop behaviour of moment-resisting joints is in contrast to the push-pull behaviour of nailed plywood specimens (Refs D4, D7, D10) at modest nail deflection values, as shown in Fig 8 .

\subsection{Sheathed Walls - Various Materials}

Section $C$ of the references gives eight sources of hysteresis loops for timber sheathed walls, representing work by one Japanese, one American and three New Zealand organisations. The walls studies gained their shear resistance from :

$$
\begin{aligned}
& \text { - plywood cladding } \\
& \text { - particle board cladding } \\
& \text { - plasterboard cladding } \\
& \text { - diagonal timber braces }
\end{aligned}
$$

A family of hysteresis curves from a repeated slow cyclic loading tests typical of the above research is given in Fig 5. As with moment-resisting joints, significant pinching of the loops occurs.

\subsubsection{Plywood and particle board sheathed walls}

Apart from the pinching effects, Fig 5 suggests useful energy absorbing behaviour as does the seminal work of Medearis (Ref C 8 ). The significant difference between behaviour of the wall and that of moment-resisting frames is that nail ductility is utilised at much lower frame displacements. It can be seen that the load plateau is reached before or near permissible drift limits in all the cases shown.

Cyclic load tests (Ref C5) on walls in which plywood sheathing was glued to the framing using two non-elastomeric glues, ie Caskade ' $K$ ' glue and Selleys 'No More Nails' glue, found adequate strength but very thin hysteresis loops, behaviour being essentially elastic up to failure, le brittleness was exhibited.

\subsubsection{Plasterboard sheathed walls}

These walls tested in Japan (Ref C2) give similar style of loops to the ply and particle board walls, a result supported by small specimen tests carried out in New Zealand (Ref C3).

\subsubsection{Sheathed walls with diagonal} timber braces

The Japanese tests (Refs $\mathrm{Cl}, \mathrm{C} 2$ on this type of wall exhibited similar behaviour to the other shear walls. A point to note is the asymmetrical hysteretic behaviour caused by the use of a single diagonal bracing element. Unfortunately the above references give little detail of the test specimens used.

\subsubsection{Typical loops}

Figure 6 presents typical individual loops characteristic of interstorey drift of $\mathrm{H} / 100$ ( 1 percent), and the general similarity of shape may be observed.

\subsection{Push-Pull Tests - Various}

Section $D$ of the references gives ten sources of hysteresis loops for various connection details tested under push-pull cyclic loading. Some of these tests examined models of particular joints, some were to assess element behaviour, and some were intended to simulate the behaviour of elements of different geometry, eg shear walls.

Families of hysteresis curves from repeated slow cyclic loadings tests typical of the above research are given in Figs 7 and 8 . These are for the following types of connection respectively:

- bolted timber strut

- nailed plywood side plates

The usual pinching of loops and the general similarity between Figs 7 and 8 may be readily seen.

\subsection{Bending v Push-Pull Hysteresis Loops for Nailed steel side plate Joints}

Finally it is noted that the similarity between individual loops of the above types indicate why simple push-pull models give a good indication of the characteristics of other type element or action, as concluded elsewhere (Ref D4).

\subsection{CLASSIFICATION AND COMPUTER MODELS OF JOINT HYSTERESIS}

The evidence so far available gives broady similar hysteretic behaviour for each element type. It thus is appropriate to classify and discuss the above material under the headings of 


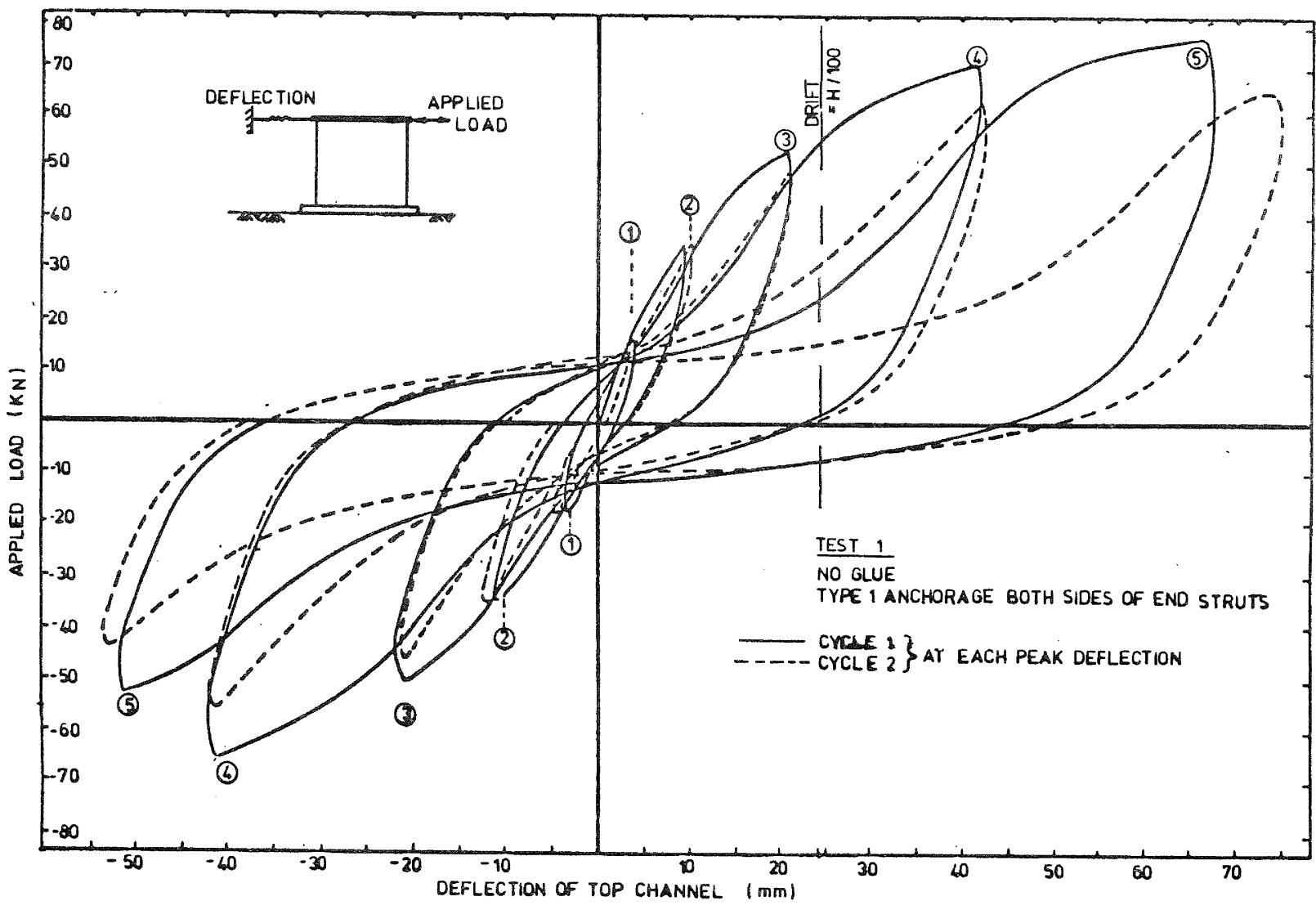

Fig 5. HYSTERESIS LOOPS FOR TIMBER FRAMED SHEAR WALLS

ALL LOOPS CHARACTERISTIC OF DRIFT = H/ WOO

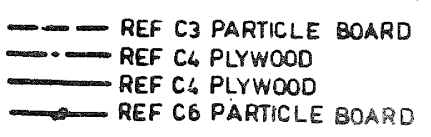

- REF C3 PARTICLE BOARD
- REF CL PLYWOOD
REF C6 PLYWOOD
- REF CG PARTICLE BOARD

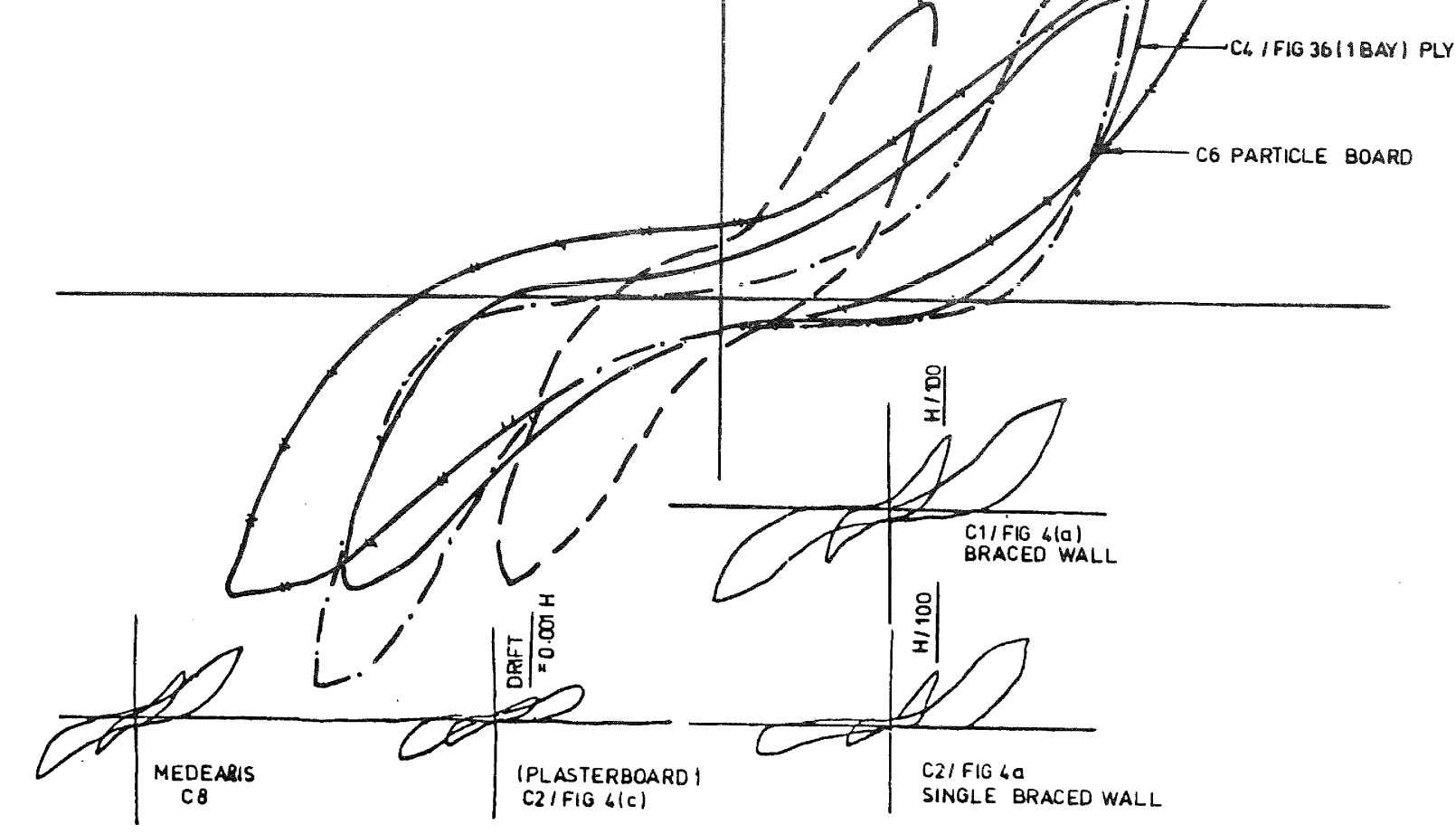

Fig 6. COMPARISON OF HYSTERESIS LOOPS FOR WALLS SHEATHED WITH DIFFERENT MATERIALS 


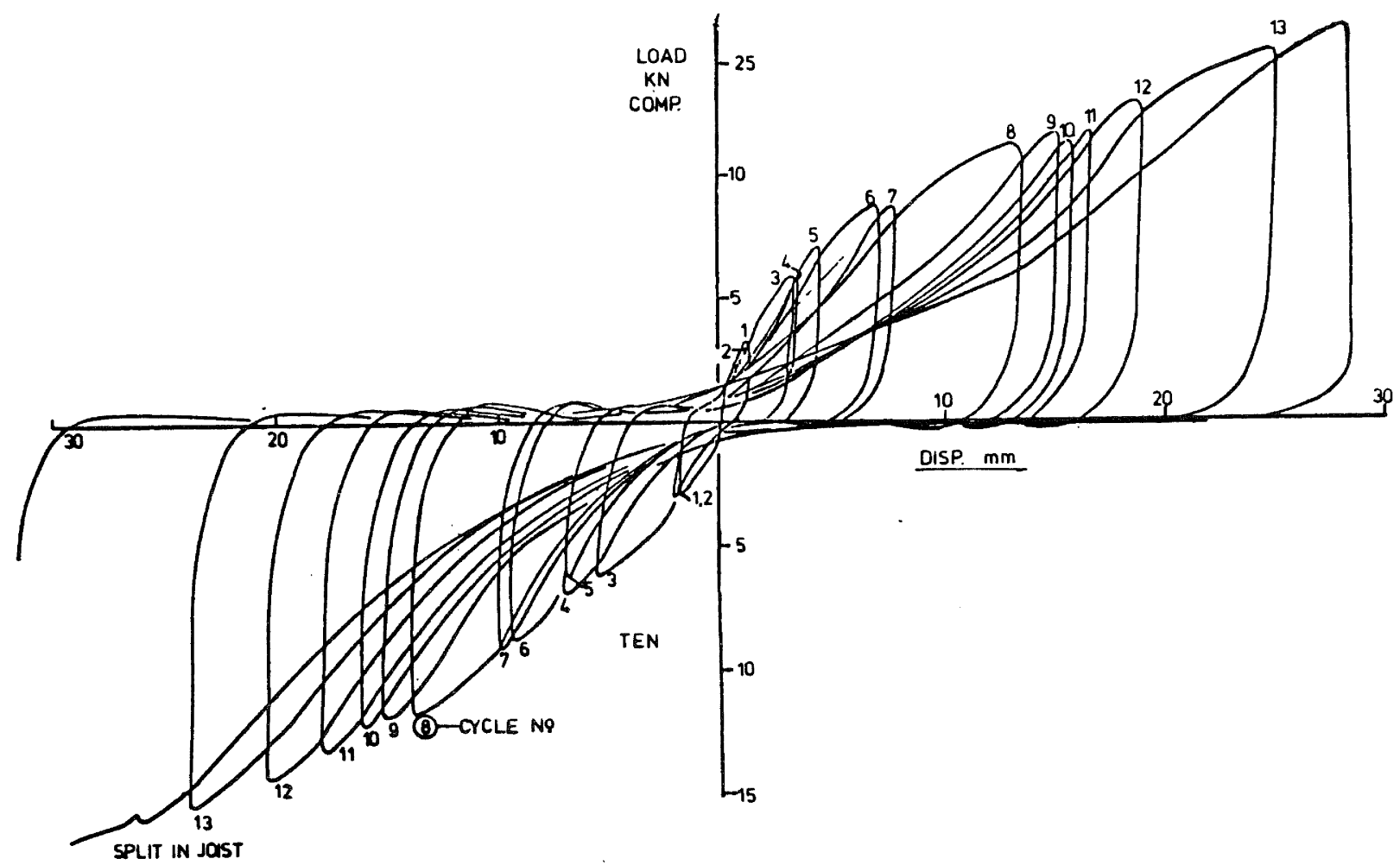

Fig 7. HYSTERESIS LOOPS FOR BOLTED TIMBER STRUT CONNECTION UNDER PUSH-PULL LOADING (REF.D1).

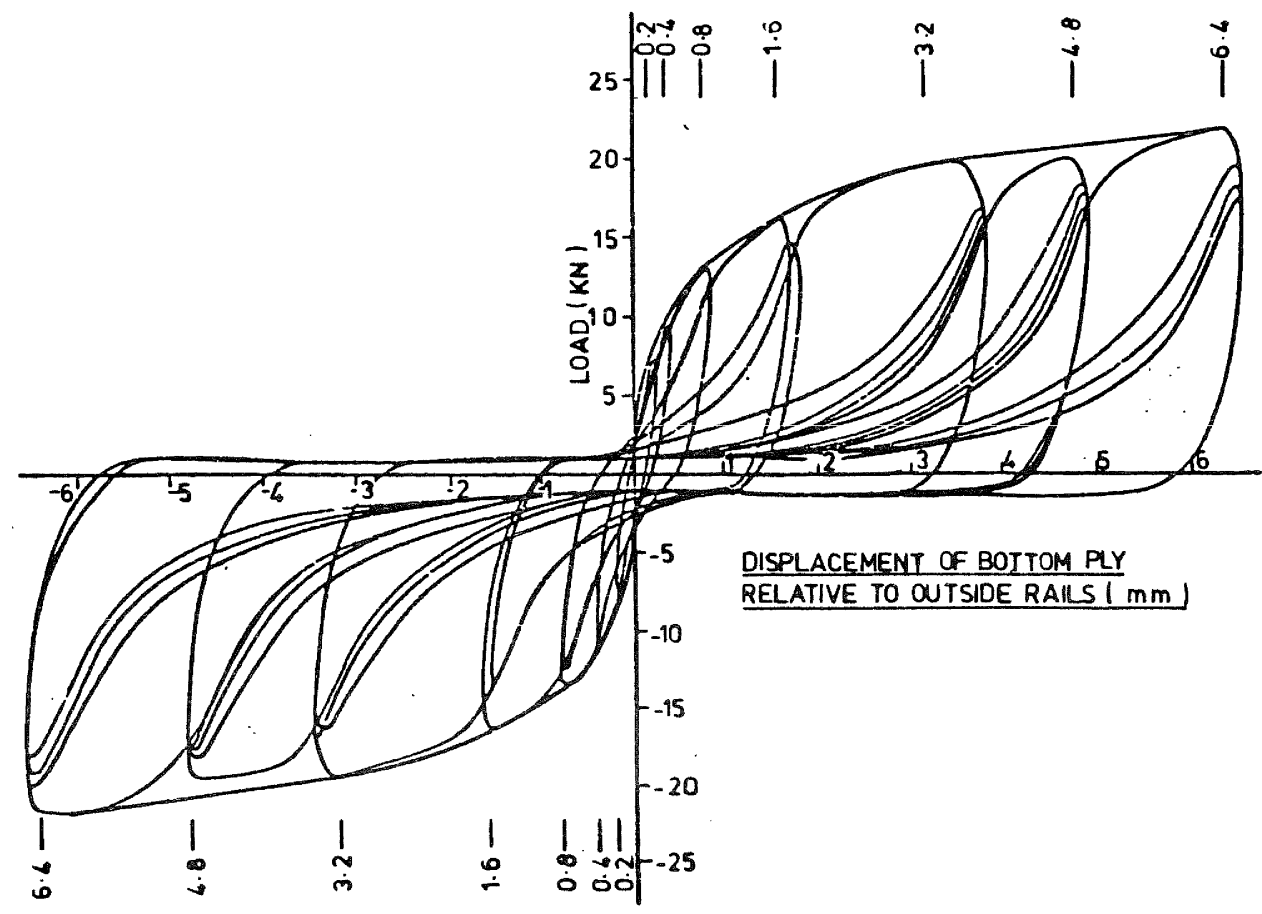

Fig 8. HYSTERESIS LOOPS FOR JOINT WITH NAILED PLYWOOD SIDE PLATES UNDER PUSH-PULLL LOADING (REF. D4). 
the three items at which yielding occurs, ie

$$
\begin{aligned}
& \text { nails } \\
& \text { nail-plates } \\
& \text { bolts }
\end{aligned}
$$

\subsection{Joints with Yielding Nails}

As illustrated in Fig 9 there are three characteristic shapes of loop. dependent on the strain level and joint type. Figure $9(\mathrm{~b})$ shows the familiar cigar shape with slight reverse curvature, which is common to all yielding nail elements at intermediate strain levels, and with moment-resisting frames it persists to very high strain because of the influence of the elastic bending deformations of the timber members. It is also noted that as usual the mean stiffness of the loop always decreases with increasing peak strain.
The loop in Fig 9 (b) could be modelled with modest to fair accuracy by all of the five model shapes shown in Figs 10 and 11, which are discussed later.

The S-shaped loop for highly strained steel side plate joints (Fig 9c) could reasonably be modelled using any one of Figs $10(b)$, (c) (d) or Fig 11 .

\subsection{Joints with Yielding Nail Plates}

The hsyteretic behaviour for necked steel side plate joints (Fig 3) would be most accurately modelled by the familiar Ramberg-osgood formulation (Fig 12(a)), although a bi-linear model could also be reasonably accurate.

\subsection{Joints with Yielding Bolts}

The bolt hysteretic behaviour for push-pull action shown in Fig 7 is simply

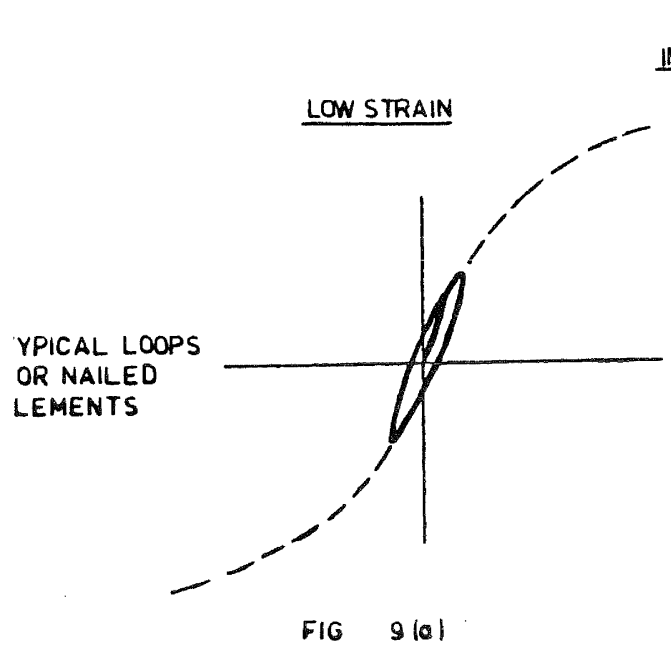

INTERMEDIATE STRA IN ALL NAILS ELEMENTS
(EXCEPT NECKED STEEL P.1)

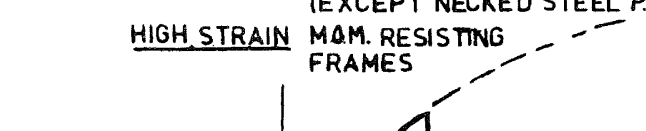

HIGH STRAIN NAILED ELEMENTS EXCEPT MOM. RESISTING PLY PLATES \& NECKED STEEL PL.

Fig 9. JOINTS WITH YIELDING NAILS

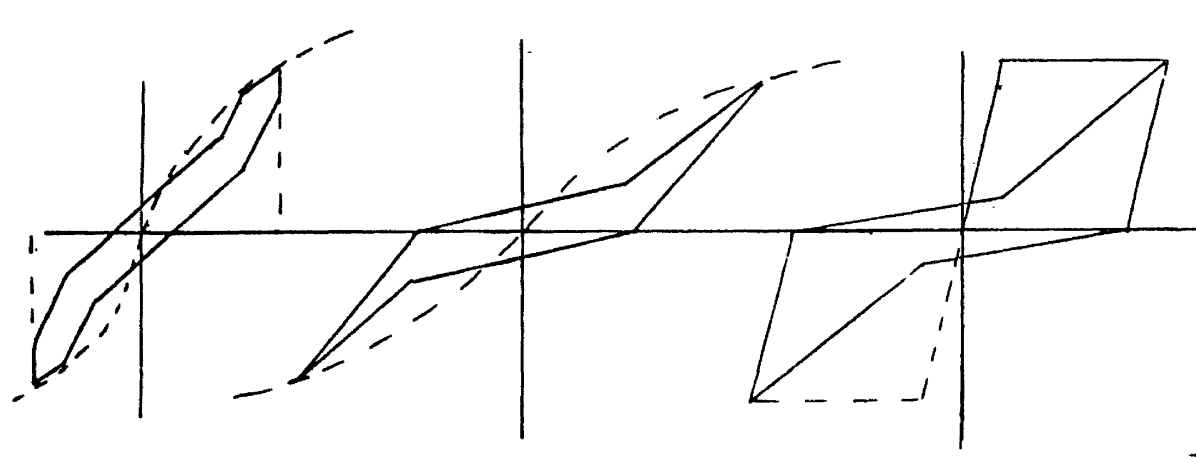

FIG $D(a)$

MODEL FOR FIG $9(b)$
FIG $10(\mathrm{D})$

GENERAL MODEL ( WOVELL of al.REF M.1)
FIG $10(c)$

GENERAL MODEL I THOM , REF. M3 I DRAIN 2-D

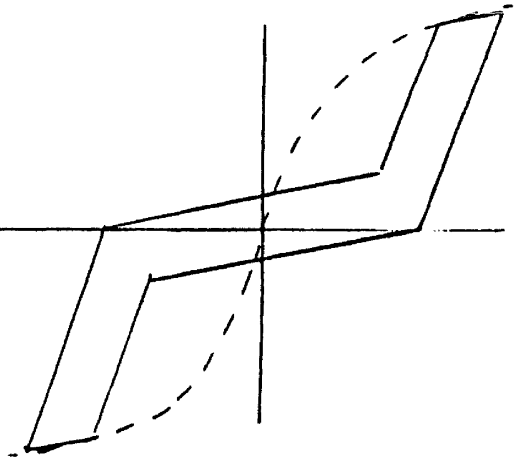

FIG $10(d)$

GENERAL MODEL (MITCHELLITHURSTON REF MG )

Fig 10. SIMPLIFIED HYSTERETIC MODELS FOR COMPUTER ANALYSIS 


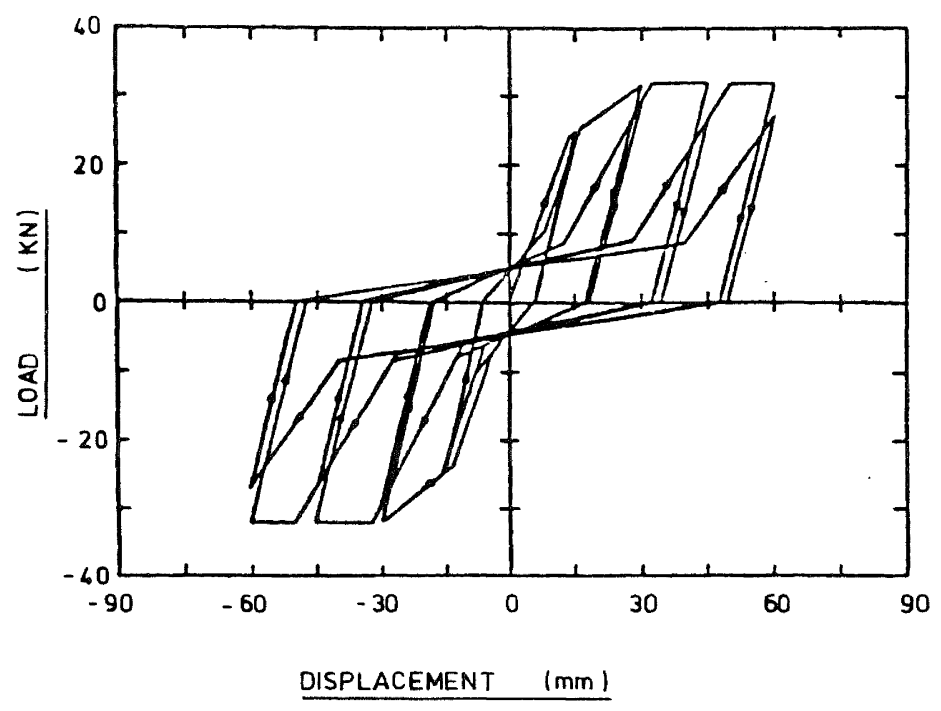

Fig 11. PINCHING HYSTERESIS MODEL (REF. M2)
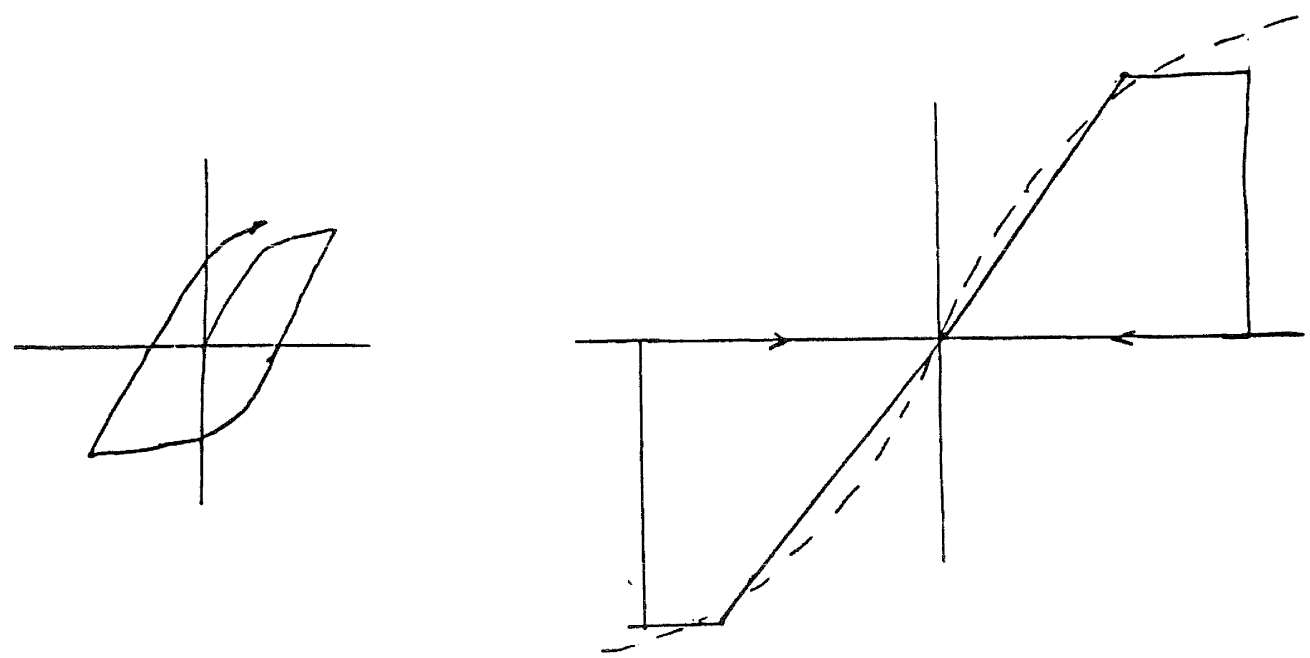

(A) RAMBERG - OSGOOD MODEL

(B) MODEL FOR BOLTED JOINTS

FOR NECKED STEE PLATE

Fig 12. FURTHER HYSTERESIS MODELS

modelled in Fig 12 (b) or more systematically modelled using the same basic shape in Fig 11 .

\subsection{Computer Modelling}

For the non-linear response-
history analyses proposed for a subsequent study, two computer programs which are commercially available in New zealand could be used. namely RUAUMOKO (University of Canterbury) and DRAIN-2D, and hysteresis models already mounted on these programs would therefore obviously be preferred unless they were technically unsatisfactory.

RUAUMOKO currently has models from Figs $10(\mathrm{~b})$ and 12 (a) available. Fig $10(b)$ comes from Kivell et al.
(Ref Ml) while Fig 12 (a) comes from current research by Stewart (Ref M2).

DRAIN-2D has Fig $10(\mathrm{c})$ and $12(\mathrm{a})$ currently available, but implementing further models is a major undertaking. Fig $10(\mathrm{c})$ is a recent addition to DRAIN-2D formulated by Thorn (Ref.M3).

As Eigures $10(\mathrm{~b})$ and/or 11 are perhaps the most appropriate for modeliling all but the necked steel plate joint. RUAUMOKO would appear to be the better of the two programs, at least for hysteretic modelling purposes, for the proposed analytical studies.

\section{CONCLUSIONS}

(1) The hysteresis loops for nail yielding connections in timber structures 
may be classified into three shapes which develop from each other with change in strain level.

(2) The hysteretic loops for bolted connections have a form similar to, but simpler than, the high strain loops for nail yielding steel side-plate joints.

(3) Yielding steel side plate joints in bending have the hysteretic behaviour of stable steelwork beam members.

(4) The loop shapes considered to be typical of the experimental results can be modelled for dynamic analysis reasonably accurately by currently available computer models.

(5) Of the two programs considered, RUAUMOKO appears to have better loop models than DRAIN-2D, for the shapes required.

(6) All of the hysteresis loops so far produced have been derived from slow or relatively slow cyclic loading. Verification of results to data by real earthquake frequency loadings (Shaketable tests) is desirable.

(7) As the New zealand earthquake code permits 2 percent interstorey drift under the design earthquake real loadings, hysteretic loops for up to that level of deformation may be considered in subsequent studies.

(8) Glued sheathed wall construction (using non-elastomeric glues) will behave in a brittle fashion, unless holding down connections are designed to yield first.

\section{ACKNOWLEDGEMENT}

This paper presents the findings of a report named "Study defining hysteresis loops for timber structures" produced by the author under contract to the Building Research Association of New Zealand in February 1985. The kind permission of BRANZ to publish this paper is gratefully acknowledged.

\section{REE ERENCES}

\section{A. Moment-Resisting Joints - Steel side plates}

A1. Bryant, A $\mathrm{H}$, Gibson, J A and Thurston, $S \mathrm{~J}$, (1981) "Nailed moment joints in timber structures", Bull. $\mathrm{NZ}$ Nat. Soc. for Earthq. Eng., Vol 14, No 4 , pp 223-232.

A2. Kivell, B $T$, Moss, $P \mathrm{~J}$ and Carr, A J, (1982) "The cyclic load behaviour of two moment-resisting nailed timber portal irames", Trans. Inst. Prof. Engineers NZ, Vol 9, 2/CE, 54-64.

A3. Prime, G N (1980) "Investigation of nail-plate joints for timber members", University of Auckland, Dept. of Civil Eng., Report No 232 .

A4. Thurston, $\mathrm{S} J$ and Flack, $\mathrm{P} F$ (1979) "Cyclic loading of large timber $T$ joints incorporating nailed steel side plates", NZ Ministry of Works and Development, Central Laboratories, Report No $5-79 / 6$

A5. Yap, K K (1984) "An investigation of damping characteristics and seismic response of ply-box and nail-plate portal frames" NZ Ministry of Works and Development, Central Laboratories. Report No 5-84/12.

\section{B. Moment-Resisting Joints

$$
\text { plywood Side plates }
$$

B1. Yap (1984) - As Ref A5.

B2. Batchelar, $M I$ and Cavanagh, G $J$ (1984) "Nailed plywood gusset joints for timber portal frames", proc. pacific Timber Eng a Conf., Auckland, Vol II, pp 631-642.

B3. Batchelar, M L (1984) "Improved plywood gussets for timber portal frames", Proc. Pacific Timber Eng. Conf. Auckland, Vol II, pp 654-666.

B4. Batchelar, M L (1983) "The behaviour of timber portal frame knee joints with nailed plywood gussets", NZ Timber Design Society, Newsletter No 13 , pp 16-47.

\section{Sheathed Walls}

C1. Sakamoto, I, Ohashi, $Y$ and Shibata, M (1984) "Theoretical analysis of seismic response of wooden dwellings in Japan" Proc. Pacific timber Eng. Conf., Auckland, Vol II, pp 454-461.

C2. Sakamoto, I, Ohashi, $Y$ and Shibata, M (1984) "Some problems and considerations on aseismic design of wooden dwelling houses in Japan", 8th world Conf. on Earthq. Eng., San Fransisco, Vol V, pp 669-676.

C3. Thurston, $S \mathrm{~J}$ and Flack, P F (1980) "Cyclic load performances of timber sheathed bracing walls", NZMWD Central Labs, Report No 5-80/10.

C4. Thurston, S J (1984) "In-plane cyclic shear tests on ply-sheathed bracing walls", NZMWD Central rabs, Report No 5-84/2.

C5. Yap, K K (1985) "Slow cyclic testing of shear panels bonded with adhesives", NZMWD Central Labs, Report No $5-85 / 14$.

C6. Cooney, $\mathrm{R} C$, Building Research Assn. of N2, Personal communication re unpublished tests on particle board sheathed walls by Brickell Moss Rankine and Hill.

C7. Cooney, R C, unpublished test results similar to those of Ref $C G$.

C8. Medearis, K (1966) "Static and dynamic properties of shear structures", proc. Int. Symp. Effects of Repeated Loading on Materials and structures, RILEM-Inst. Ing., Mexico, VI. 
D. Miscellaneous Connection Methods Dl. wood, J H, Cooney, R C and
Potter, S M (1976) "Cyclic testing of
connections for
construction", NZMwD Central Labs, Report
No 5-76/12 (Bolts, Pryde Nail plates,
etc).

D2. Thurston, $S \mathrm{~J}$ and Flack, $\mathrm{P} F$ (1979) "Monotonic and cyclic testing of timber connections used nailed steel side plates", NZMWD Central Labs, Report No $5-79 / 4$.

D3. Thurston and Elack (1979) - As Ref A4.

D4. Thurston, $S \mathrm{~J}$ and Hutchison, D I (1984) "Cyclic load testing of timbersheathed wall panels" "Proc. Pacific Timber Eng. Conf., Auckland, Vol II, 486-503 (Plywood).

D5. Stewart, $W$, Dean, $J$ A and Carr, A J (1984) "The seismic performance of plywood sheathed shearwalls", proc. Pacific Timber Eng. Conf., Auckland. Vol II, pp 486-495.

D6. Lowe, P G and Edwards, M R (1984) "Aspects of ductility of nailed timber connections", Proc. Pacific Timber Eng. Conf., Auckland, Vol II, pp 622-630.

D7. Prime (1980) - As Ref A3.

D8. Dean, J A, Rowlands, $B$ W and Parrott, M M (1984) "Testing of a ductile nailed spliced joint of timber structure" "University of Canterbury. Dept. of Civil Eng.. Research Report No $84-16$.

D9. Gangnail plate test result (unpublished).

D10. Ditto.

M. Modelling (for Non-linear response-history analysis)

MI. Kivell, $B$ T, Moss, $P$ J and Carr, A J (1981) "Hysteretic modelling of moment-resisting nailed timber joints", Bull. NZ Nat. Soc. for Earthq. Eng., Vol 14, No 4, pp 233-243.

M2. Stewart, W G (1985) Personal communication regarding doctoral thesis research at the University of Canterbury, currently in progress.

M3. Thom, CW (1983) "The effects of inelastic shear on the seismic response of structures", Univ. of Auckland, Dept. Civil Eng., Report No 347.

M4. Mitchell, T N (1979) "Seismic design of timber structures", proc. 2nd Sth. Pacific Regional Conf. on Earthq. Eng., Wellington, pp 716-737. 